\title{
Prevent Sudden Death in Carvajal Syndrome With Left Ventricular Hypertrabeculation/Noncompaction
}

\author{
Claudia Stollberger, ${ }^{1, *}$ and Josef Finsterer ${ }^{1}$ \\ ${ }^{1}$ Rudolfstiftung Hospital, Vienna, Austria \\ "Corresponding author: Claudia Stollberger, Rudolfstiftung Hospital, Juchgasse, Vienna, Austria. Tel: +43-6764031187, Fax: +43-1711652209, E-mail: \\ claudia.stoellberger@chello.at
}

Received 2015 October 11; Revised 2015 December 21; Accepted 2015 December 30.

Keywords: Carvajal Syndrome, Left Ventricular Hypertrabeculation

\section{Dear Editor,}

With interest we read the article by Mohammadpour Ahranjani et al. about a nine-year-old girl with heart failure due to systolic dysfunction and left ventricular hypertrabeculation/noncompaction (LVHT) in whom the association with skin abnormalities led to the diagnosis of Caravajal syndrome (CS) (1). We have the following questions and concerns: mutations in the desmoplakin genes have been identified in some patients with CS. However, there are also CS-cases in whom no mutations of the desmoplakin gene have been found thus indicating genetic heterogeneity(2). It would be interesting to know if genetic studies were carried out in the presented patient.

In the case report we miss information about the family history of the patient. It is only indicated that two cousins suffered also from skin lesions and it remains unclear if they were investigated by a cardiologist and dermatologist. Since CS seems to be autosomal recessively inherited it would be of interest if the patient's parents were consanguineous and if other family members showed any cardiac, skin or hair anomalies.

CS may also be inherited as an autosomal dominant disease. In these cases, dental anomalies have been found (2-6). Thus, information about dental anomalies in the presented patient or in her family would be of interest.

Regarding the patient's history, we would like to know if there were any other health problems during pregnancy or early childhood except the skin problems and about her intellectual development. It is mentioned that she was diagnosed with anemia at age 8 years, but the type of anemia and the therapy are not indicated.

CS is characterized by woolly hair. We miss the description of the patient's hair.

CS manifests frequently with arrhythmias, even leading to sudden death (4-6). Thus, it would be of interest to get information about any electrocardiographic abnor- malities and whether she had a history of syncope, vertigo or spells suggesting arrhythmia which are reported to precede sudden death (7). If carried out, results of 24-hour Holter monitoring and bicycle stress testing are of interest. Implantation of a defibrillator (ICD) is reported in patients with CS and we miss information if this was considered in the presented patient $(3,6)$. Application of a wearable defibrillator (live vest) could be an alternative to protect her from sudden death and to defer placement of an ICD, or implantation of a loop recorder to more effectively assess the risk of ventricular arrhythmias and sudden death and to support the indication for an ICD.

The patient suffered from systolic dysfunction of the left ventricle. It would be of interest if the right ventricle did also show any abnormalities.

CS associated with LVHT has been reported in only 3 cases $(2,5,8)$. The location of LVHT within the left ventricle should be described more precisely and how it was differentiated from thrombi, papillary muscles, or aberrant bands. Since the presented echocardiograms date from the year 2012, recent follow-up data could be useful. It would be interesting to know if LVHT changed in size and degree, if left ventricular function improved and left ventricular diameter decreased after successful heart failure therapy.

Since LVHT is frequently associated with neuromuscular disorders it would be of interest to know if the patient was investigated neurologically and if she had a family history of a neuromuscular disorder (9).

In the end of the discussion, the authors state that "we need much more time for the follow-up, cannot conclude clearly about the prognosis..." (1). Although CS as well as LVHT are rare disorders, there are sufficient data which indicate that both diagnoses in children and young adults are associated with a high risk for sudden death (10). Thus, careful follow-up and protection from sudden death seem mandatory in the presented patient. 
Overall, it would be helpful to present more relevant background information, information about followup data, and information about risk stratification and risk management.

\section{References}

1. Mohammadpour Ahranjani B, Moradi P, Nazari S, Farshadfar S. A Nine-Year-Old Girl With Left Ventricle Non-Compaction and Skin Lesions (Carvajal Syndrome). Iran J Pediatr. 2015;25(4):e370. doi: 10.5812/ijp.370. [PubMed: 26396705].

2. Nehme N, El Malti R, Roux-Buisson N, Caignault JR, Bouvagnet P. Evidence for genetic heterogeneity in Carvajal syndrome. Cell Tissue Res. 2012;348(2):261-4. doi: 10.1007/s00441-012-1351-6. [PubMed: 22350851].

3. Boule S, Fressart V, Laux D, Mallet A, Simon F, de Groote P, et al. Expanding the phenotype associated with a desmoplakin dominant mutation: Carvajal/Naxos syndrome associated with leukonychia and oligodontia. Int J Cardiol. 2012;161(1):50-2. doi: 10.1016/j.ijcard.2012.06.068. [PubMed: 22795705].

4. Barber S, Day P, Judge M, Toole EO, Fayle S. Variant Carvajal syndrome with additional dental anomalies. Int J Paediatr Dent. 2012;22(5):3906. doi:10.1111/j.1365-263X.2012.01230.x. [PubMed: 22404234].

5. Mahoney MG, Sadowski S, Brennan D, Pikander P, Saukko P, Wahl J, et al. Compound heterozygous desmoplakin mutations result in a phenotype with a combination of myocardial, skin, hair, and enamel abnormalities. J Invest Dermatol. 2010;130(4):968-78. doi: 10.1038/jid.2009.357. [PubMed: 19924139].

6. Norgett EE, Lucke TW, Bowers B, Munro CS, Leigh IM, Kelsell DP. Early death from cardiomyopathy in a family with autosomal dominant striate palmoplantar keratoderma and woolly hair associated with a novel insertion mutation in desmoplakin. J Invest Dermatol. 2006;126(7):1651-4. doi: 10.1038/sj.jid.5700291. [PubMed: 16628197].

7. Drezner JA, Fudge J, Harmon KG, Berger S, Campbell RM, Vetter VL. Warning symptoms and family history in children and young adults with sudden cardiac arrest. J Am Board Fam Med. 2012;25(4):408-15. doi: 10.3122/jabfm.2012.04.110225. [PubMed: 22773708].

8. Williams T, Machann W, Kuhler L, Hamm H, Muller-Hocker J, Zimmer M, et al. Novel desmoplakin mutation: juvenile biventricular cardiomyopathy with left ventricular non-compaction and acantholytic palmoplantar keratoderma. Clin Res Cardiol. 2011;100(12):1087-93. doi: 10.1007/s00392-011-0345-9. [PubMed: 21789513].

9. Stollberger C, Blazek G, Gessner M, Bichler K, Wegner C, Finsterer J. Age-dependency of cardiac and neuromuscular findings in adults with left ventricular hypertrabeculation/noncompaction. Am J Cardiol. 2015;115(9):1287-92. doi: 10.1016/j.amjcard.2015.02.014. [PubMed 25791238].

10. Bharucha T, Lee KJ, Daubeney PE, Nugent AW, Turner C, Sholler GF, et al. Sudden death in childhood cardiomyopathy: results from a long-term national population-based study. J Am Coll Cardiol. 2015;65(21):2302-10. doi: 10.1016/j.jacc.2015.03.552. [PubMed: 26022819]. 